\title{
Taxonomic and biogeographical observations on a new pop- ulation of Calomera Motschulsky, 1862 (Coleoptera Cara- bidae Cicindelinae) from Crete Island (Greece)
}

\author{
Marcello Romano' \& Ignazio Sparacio² \\ ${ }^{1}$ Piazza A. Cataldo 10, 90040 Capaci (Palermo), Italy; e-mail: marcellr@libero.it \\ ${ }^{2}$ Via Principe di Paternò 3, 90144 Palermo, Italy; e-mail: edizionidanaus@gmail.com
}

\begin{abstract}
During a wildlife expedition to Crete Island (Greece), we found a population of Calomera Motschulsky, 1862 (Coleoptera Carabidae Cicindelinae), which was new to this island and that we describe as a new subspecies (C. panormitana cretensis n. ssp.). In this paper, some taxonomic and biogeographical observations on the C. aphrodisia (Baudi di Selve, 1864) group are provided, the validity of the taxon C. panormitana is confirmed, and, for nomenclatural stability, a neotypus of C. lugens Dejean, 1831, and a lectotypus of C. panormitana are designated.
\end{abstract}

KEY WORDS Calomera aphrodisia; panormitana; speciation; Mediterranean.

Received 03.05.2018; accepted 18.07.2018; printed 30.09.2018; published online 05.10.2018

\section{INTRODUCTION}

Calomera aphrodisia (Baudi di Selve, 1864) (Coleoptera Carabidae Cicindelinae) was described as a "variety" of $C$. littoralis (Fabricius, 1787) on the basis of specimens collected by Eugenio Truqui in "insula Cypro et Asia Minor" (Baudi di Selve, 1864).

Ragusa (1882) discovered in Sicily, in the same day and in the same locality, "Cicindela littoralis var. lugens Dahl." and "Cicindela littoralis var. aphrodisia Truqui”. Subsequently, Ragusa (1884, 1904) better distinguished the two mentioned taxa by describing the Sicilian populations of C. aphrodisia as a distinct variety that he named "panormitana" (Ragusa, 1906).

Piochard de la Brulerie (1885) and Horn \& Roeschke (1891), among the two original localities mentioned by Baudi di Selve (1864) for C. aphrodisia, reported Cyprus as the locus typicus of this species. Horn (1931) observed that the populations coming from these two localities are different from each other and that the description of Baudi di Selve (1864) corresponded to those coming from the Syrian coasts. Mandl (1981) confirmed these observations and described the populations of Cyprus and Rhodes as a distinct subspecies (cypricola).

Cassola (1983, sub Lophyridia aphrodisia panormitana) made a detailed review of the literature on the presence and biology of $C$. panormitana in Sicily.

Wiesner (1992) considered C. panormitana as a synonym of $C$. lugens Dejean, 1831 and proposed the following classification: Calomera lugens lugens (Sicily), C. lugens cypricola (Cyprus and Rhodes), and C. aphrodisia (Turkish and Syrian coasts). Korell (1994) followed this approach. Cassola (1999) repeated what was previously stated on the Sicilian populations (Cassola, 1983), i.e., that "lugens Dejean, 1831" should refer to a chromatic variety of a species of the $C$. littoralis and not of the C. aphrodisia and he confirms the validity of $C$. panormitana. 
At the moment, some Authors, such as Franzen (2001) and Aydin (2011), follow Cassola (1983, 1999), while others follow Wiesner (1992).

During a wildlife expedition to Crete, we found a population of Calomera Motschulsky, 1862, which was new to this island and which showed some peculiar morphological characteristics. We describe below this taxon as a new subspecies, adding also some taxonomic and biogeographical observations on the whole $C$. aphrodisia group (Figs. 1-8).

\section{MATERIAL AND METHODS}

All specimens were collected on sight in their natural environment during daylight hours. In these localities, they have been photographed with a camera Canon Eos 100D - macro 100 mm (I. Sparacio). Collected samples were then prepared in laboratory and male genitalia were extracted. Laboratory photos have been taken using a Canon Eos 450D digital camera equipped with Canon MPE-65 lens and mounted on a Manfrotto micro-slider movement system. The images were then processed with Zerene Stacker 1.0.32 software by M. Romano. All the specimens were studied using an Optika light microscope and a Carl Zeiss light microscope. The taxonomic order and nomenclatural arrangement follow the cited papers.

ACRONYMS AND ABBREVIATIONS. M. Romano collection, Capaci, Palermo, Italy (CMR);

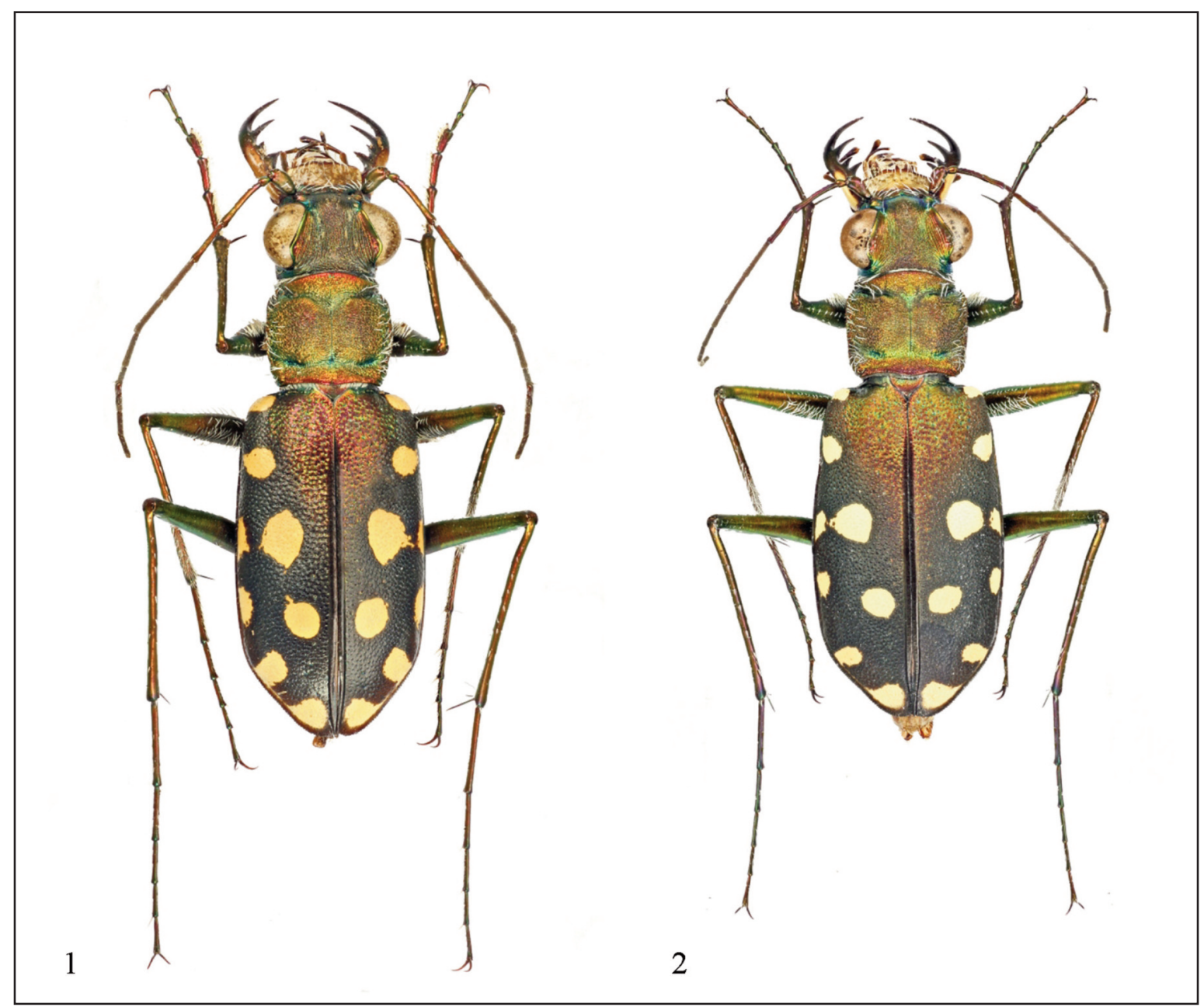

Figure 1. Calomera aphrodisia from Lebanon, Beyrouth.

Figure 2. Calomera panormitana cypricola from Cyprus, Alsancak Girne. 
I. Sparacio collection, Palermo, Italy (CIS); Collection of Dipartimento di Biologia Animale University of Catania, Italy (CMC); Collection of Museo Civico di Storia Naturale "Giacomo Doria", Genova, Italy (MCSNG); Collection of Museum National d'Histoire Naturelle, Paris, France (MNHN); $\mathrm{ex} / \mathrm{x}=$ specimen $/ \mathrm{s}$. Unless otherwise stated, the collector of the beetles in the field is also the owner of the collection where the specimens are preseved.

\section{RESULTS}

Systematics

Ordo COLEOPTERA Linnaeus, 1758
Familia CARABIDAE Latreille, 1802

Subfamilia CICINDELINAE Latreille, 1802

Genus Calomera Motschulsky, 1862

Species panormitana (Ragusa, 1906)

Calomera panormitana cretensis $\mathrm{n}$. ssp.

TyPe material. Holotype male, Creta, Chania, Daratsos， 31.V.2014， 35.51509N， 23.98947E (CIS). Paratypes: 5 exx, same locality of the holotype, 2.VI.2014, 35.51621, 23.98173E (CIS), 2 exx, idem (CMR), 1 ex, idem, legit I. Sparacio (MCSNG)

OTHER EXAMINED MATERIAL. Calomera panormitana panormitana. E. Ragusa collection (CMC): "Cicind. aulica a. panormitana Rag.": 1 ex labelled

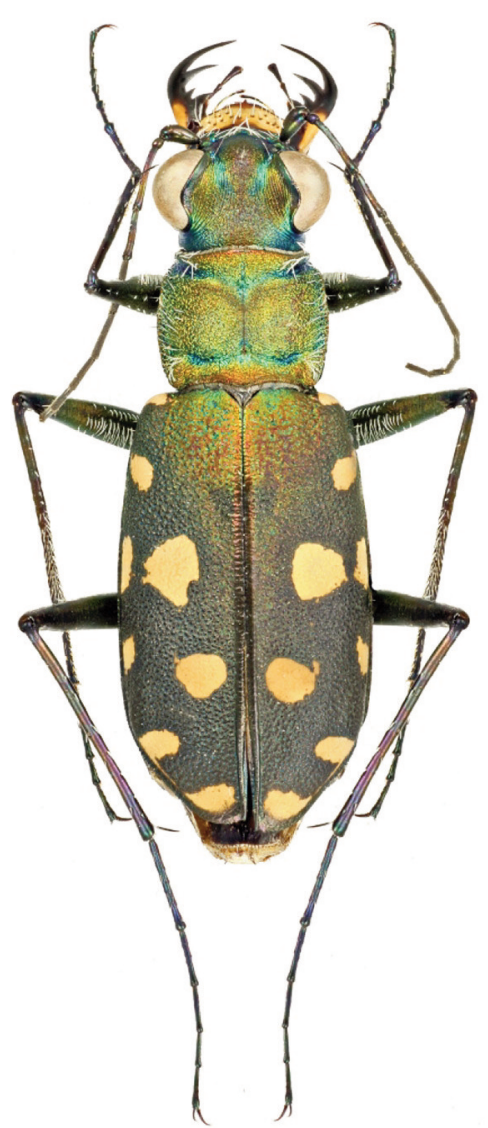

3

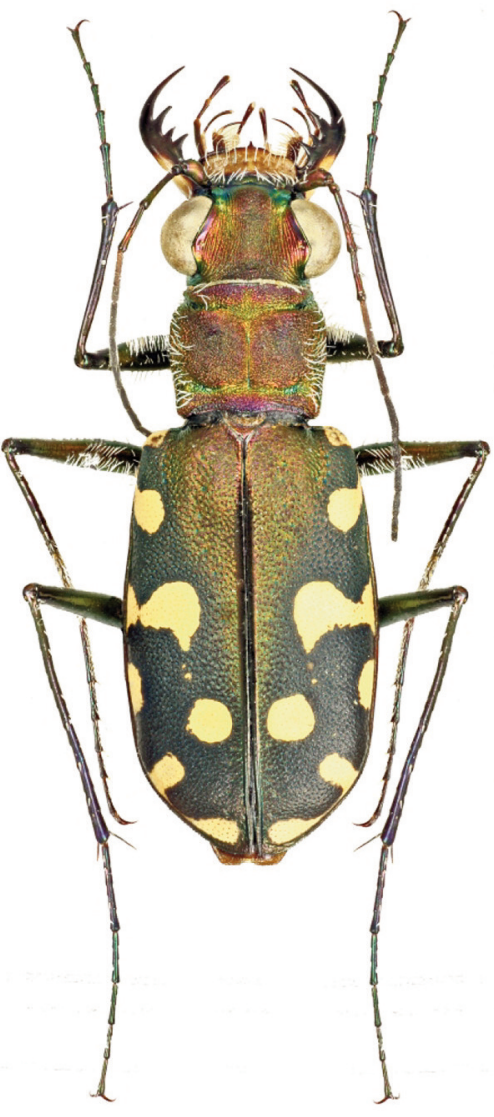

Figure 3. Calomera panormitana cretensis n. ssp., Crete (Greece), Chania, Daratsos. Figure 4. Calomera panormitana panormitana from Italy, Sicily, San Vito Lo Capo. 
"Sicilia, Mondello, E. Ragusa, 8" - red label: Calomera panormitana Ragusa, 1906 - Lectotypus, M. Romano \& I. Sparacio des. 2018; 3 exx labelled "Sicilia, Balestr.[ate], E. Ragusa, 6". 8 exx without labels; "Cicind. aulica a. lugens Rag.": 1 ex labelled "Sicilia, Mondello, 21.7.07; 1 ex labelled "Sicilia, Mondello, E. Ragusa, 8; 7 exx without labels; " $\mathrm{Ci}$ cind. aulica a. luctuosa Rag.": 1 ex labelled "Sicilia, 2.8.921, Isola scogliera, A. Modica"; 6 exx without labels. All these specimens, except the Lectotype, have a red label: Calomera panormitana Ragusa, 1906 - Paralectotypus - M. Romano \& I. Sparacio des. 2018.

San Vito Lo Capo (Trapani), 22.VII.1982, 10 exx (CMR); 23.VIII.1994, 1 ex (CMR); 23.VII.1995, 1 ex (CMR); 2.VIII.1996, 4 exx (CMR); 20.VI.1997, 18 exx (CMR).

San Vito Lo Capo (Trapani), 13.VI.1982, 3 exx (CIS); 28.VI.1997, 4 exx (CIS); Cinisi (Palermo), 6.VIII.1983, 2 exx (CIS); idem, 18.VIII.1983, 5 exx (CIS); idem, 7.VII.1986, 4 exx (CIS); idem, 19.VIII.1989, 2 exx (CIS); idem, 2.VIII.1993, 2 exx (CIS); Carini (Palermo), Torre Pozzillo, 6.VII.1985, 2 exx (CIS); Sferracavallo (Palermo), Punta Matese, 2.VIII.1986, 4 exx (CIS); idem, 6.VIII.1986, 1 ex (CIS); idem, 25.VIII.1988, 3 exx (CIS); idem, 8.VIII.1997, 1 ex (CIS); idem, 10.VII.2000, 1 ex (CIS); idem, 13.VIII.2001, 2 exx (CIS); Isola delle Femmine (Palermo), Punta della Catena, 2.VIII.1993, 2 exx (CIS); idem, 14.VIII.1993, 3 exx (CIS); Castelluzzo (Trapani): Golfo di Cofano, 5/8.VIII.2008, 8 exx (CIS); Sferracavallo (Palermo): Barcarello, 13.VIII.2011, 2 exx (CIS).

Calomera panormitana cypricola. Cipro. Cipro coll. Truqui D. Baudi 1872 - Syntypus Cicindela littoralis var. aphrodisia Baudi, 1864 (red label) - cfr. scheda 7911 - Cicindela aphrodisia det R. Gestro Museo Civico di Genova, 3 exx (MCSNG); Cipro, sud di Larabay, VIII.2005 - Lophyr. aphrodisia cypricola, 1 ex (MCSNG); Alsancak Girne Cyprus, VIII.1979 P. Cabella legit - Lophyridia aphrodisia Baudi - Lophyridia aphrodisia Baudi - Museo Genova coll. P. Cabella (dono 2011) 1 ex (MCSNG); Alsancak Girne Cipro VIII.1979 P. Cabella legit Lophyridia aphrodisia Baudi - Lophyridia aphrodisia Baudi - Museo Genova coll. P. Cabella (dono 2011) 4 exx (MCSNG).

Calomera aphrodisia. Libano. Beyrouth Acq. E. Deyrolle 1870 - Cicindela aphrodisia Baudi det. R.
Gestro - Museo Civico di Genova, 1 ex; Beyrouth Acq. E. Deyrolle 1870 / Cicindela sp. - Cicindela aphrodisia Baudi det R. Gestro - Museo Civico di Genova, 1 ex (MCSNG);

Calomera littoralis nemoralis (Olivier, 1790). Italy, Sicily, Balestrate (Palermo), Foci Torrente Calatubo, 13.V.1979, legit I. Sparacio, red label: Calomera littoralis nemoralis ab. lugens Dejean, 1831- Neotypus - M. Romano \& I. Sparacio des. 2018 (MNHN). Ragusa collection (CMC): "Cicindela ab. lugens Dej.": 1 ex labelled "Sicilia, Oreto, E. Ragusa, 4"; 1 ex labelled "Sicilia, Trapani, E. Ragusa, 8; 1 ex labelled "Cic. ab. Lugens Dej."; 1 ex labelled "Sicilia, Balestr.[ate], 19/6; 2 exx senza cartellino.

Description OF THE HolotyPe. Male. Lenght 14 $\mathrm{mm}$ (without labrum). Reddish-bronze green in colour on head, pronotum, front of the elytra, legs and ventral surface; elytra opaque, blackish in the $2 / 3$ posterior of the elytral length, with six whiteyellowish spots, well separated, of which four spots at or close to the elytral margin (one humeral, two marginal, and one apical), and two at the discal level. White pubescence is present on the head, sides of the pronotum, legs, and under side.

Head large, with 2 iuxta-orbital setigerous punctures near both eyes and 1 central: each puncture bearing a very fine, long, erect, sensorial seta. Eyes large and prominent. Frons and vertex covered with longitudinal striae, which are deeply developed near orbital edges and somewhat irregular and wrinkly in the middle; clypeus hollow in the middle; labrum testaceous, transverse, nearly three times wider than long, distinctly tridentate forwards (longer median tooth), and 15 long hairs. Mandibles long and pointed, testaceous on the sides of the base. Labial and maxillary palpi black, yellow at the apex; last segment with wider and rounded apex; penultimate segment of maxyllary palpi a little shorter. Antennae long, reaching approximately the middle of the elytral length; scape and 2-4 antennomeres glabrous, metallic, with only $2-3$ short hairs; antennomeres 5-11 finely and evenly pubescent with some longer sparse hairs.

Pronotum wider than long (with of pronotum/length of pronotum: 1.18), subparallel sided, slightly wider forward, with dense white decumbent hairs covering the sides; central disk glabrous; front edge slightly protruding forward; anterior and posterior grooves deep; surface wrin- 
kled with numerous, dense, and irregular longitudinal striae converging on the median longitudinal groove.

Scutellum triangular with micro-wrinkled surface. Elytra elongated, partially subparallel sided, slightly wider towards the middle, gradually rounded to apical angle, micro-denticulate in their back curve; sculpture formed by small granules well spaced from each other on a finely and regularly microrugous surface.

Abdominal sternites with some punctures on the front and back edges. Legs long, anterior and middle femora with dense, short, and white pubescence; posterior tarsi slightly longer than the corresponding tibiae.

Shape of median lobes of the aedeagus (Fig. 7) wider and shorter forward, longer and arched in the posterior part, apex rounded with the tip slightly curved upwards and with little punctures, lateroapical crest long and detected.

VARIABILITY. The paratypes do not show appreciable morphological differences compared to the holotype. The body length is $13-16 \mathrm{~mm}$; the greenish reflections in some specimens are less evident; labrum with 14-20 long hairs; the females have greater body length and wider elytra.

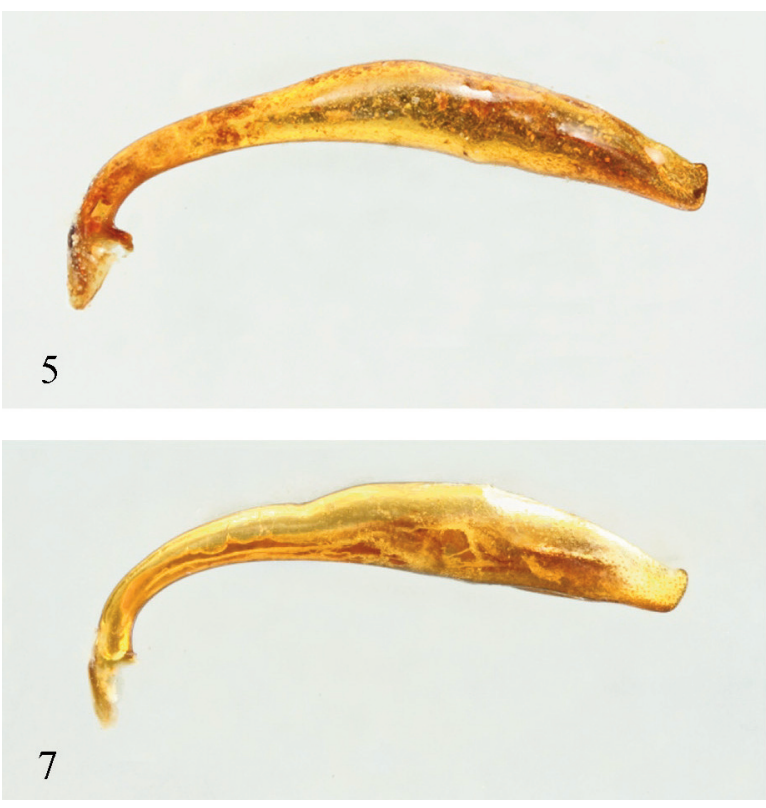

ETymology. The subspecific epithet refers to the type locality, Crete, the largest of the Greek islands.

Biology And DistRibution. Calomera panormitana cretensis $\mathrm{n}$. ssp. is found in rocky habitats in the littoral zone, as all the taxa of the aphrodisia group (Ragusa, 1906; Horn 1931, Cassola, 1983, 1999; Sparacio, 1994; Franzen 2001; Lisa, 2002; Austin et al., 2008; Aydin, 2011). Calomera species feed on Ligia spp. (Isopoda) and other small invertebrates such as Littorina spp. and Gibbula spp. (Mollusca). Adults are active during late Spring and Summer months (May to August). Larval development occurs in the same habitat of adults (see Cassola, 1983).

Calomera panormitana cretensis $\mathrm{n}$. ssp. is, at present, only known from the type locality (Figs. 9, 10), but it is likely that this subspecies occurs also elsewhere in Crete, in suitable habitat, which have not yet been explored. Calomera panormitana panormitana is endemic to Sicily. Calomera panormitana cypricola lives in Cyprus, Rhodes, and SWTurkey. Calomera aphrodisia is reported from few localities in southern Turkey, Syria, Lebanon, and Israel (Tschitscherine, 1903; Horn, 1931; Korell, 1994; Franzen, 2001; Avgin \& Wiesner, 2009; Jaskuła \& Rewicz, 2014; Assmann, 2018).

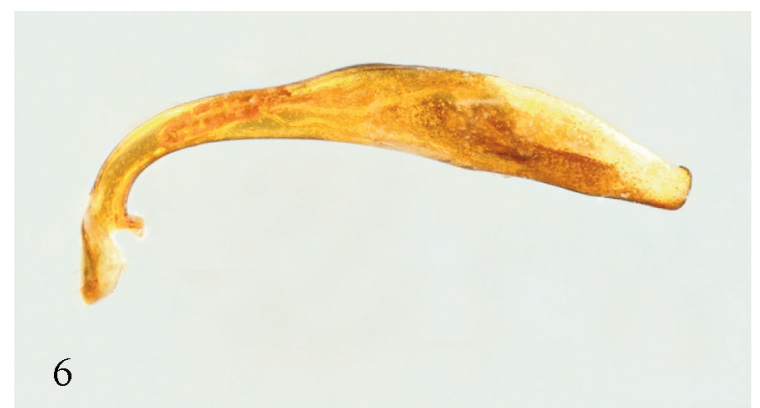

8

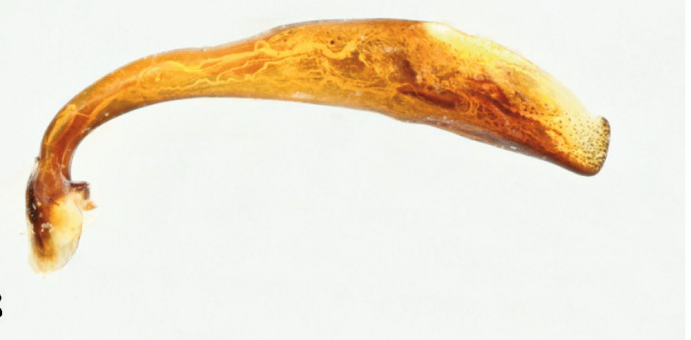

Figures 5-8. Aedeagi of Calomera aphrodisia from Lebanon, Beyrouth (Fig. 5), C. panormitana cypricola from Cyprus, Alsancak Girne (Fig. 6), C. panormitana cretensis n. ssp., Crete, Chania, Daratsos (Fig. 7), C. panormitana panormitana from Italy, Sicily, San Vito Lo Capo (Fig. 8). 
CONSERVATION. Tiger beetles are good indicators for habitat changes (Pearson \& Cassola, 1992; Rodrigues et al., 1998; Cassola \& Pearson, 2000, Pearson \& Vogler, 2001; Aydın, 2006, 2011; Choate, 2010).

The species of the C. aphrodisia group, in particular, are relics species in the Eastern Mediterranean with very small or restricted populations and in constant reduction. They are herein classified as Vulnerable taxa (VU, according to the IUCN Red List of Threatened Species Categories, 2017), with a high risk of extinction (see Aydın, 2011 and cited references). The decline of these species is due to habitat degradation by human activity and to disturbance due to Summer tourism.

Calomera panormitana cretensis n. ssp. is classified, at the moment, as Vulnerable (VU).

Comparative Notes. Morphologically we can distinguish two groups as follows:

1. Narrower, elongate, bright, forebody and elytra darker. Elytra subparallel sides, narrower in the apical third with sculpture formed by big granules, often converging on the sides, on a large microwrinkeld surface. Posterior tarsus much longer than the corresponding tibias (1.32-1.35). Shape of median lobes of the aedeagus slender, little widened at the middle, short and slightly arched in the posterior part, apex rounded with the tip protruding and slightly curved upwards, latero-apical crest long and detected .Calomera aphrodisia

-. Larger, especially in the posterior part of the elytra and in the females, opaque, reddish-bronze or greenish-bronze in colour on head, pronotum, front of the elytra, blackish in the $2 / 3$ posterior of the elytra; elytra with arched sides, dilated and rounded in the apical third with sculpture formed by little and spaced granules on a finely microwrinkled surface. Posterior tarsus a little longer than the corresponding tibias (1.04-1.16). Shape of median lobes of the aedeagus enlarged after the middle, longer and arched in the posterior part, latero-apical crest shorter and less detected. ....2

2. Body on average larger, lenght $13-16 \mathrm{~mm}$; coloration dorsal surface less dark; discal spot of the elytra small, not extensive, usually well separated from the marginal spot or just united. Pronotum transverse, wider than long. Granules of the elytra smaller and more spaced. Shape of median lobes of the aedeagus less dilated forward.
-. Body on average smaller, lenght $12-14.5 \mathrm{~mm}$; coloration dorsal surface darker, often blackish; discal spot of the elytra bigger, often united with the marginal spot and with that lower discal. Pronotum short and narrow, slightly wider than long. Granules of the elytra larger and irregular arranged. Shape of median lobes of the aedeagus wider and shorter forward, apex with little punctures, latero-apical crest longer and detected.

Calomera panormitana panormitana

3. Larger body; anterior part of the dorsal surface greenish-bronze in colour. Pronotum clearly wider than long. Shape of median lobes of the aedeagus longer, latero-apical crest little short, apical punctures fairly extensive

Calomera panormitana cretensis $\mathrm{n}$. ssp.

4. Body less wide; anterior part of the dorsal surface reddish-bronze in colour. Pronotum less transverse. Shape of median lobes of the aedeagus longer, latero-apical crest shorter, apical punctures very extensive......Calomera panormitana cypricola

Remarks. The $C$. aphrodisia species group has several nomenclatural problems mainly due to designation of the locus typicus of C. aphrodisia and, more recently, with the use of the name panormitana.

Ragusa (1882), along the beach of Mondello, on the same day, collected for the first time in Sicily two different forms of taxa then classified as belonging to the genus Cicindela Linnaeus, 1758: the specimens with the seven-shaped elitral stain were attributed to "Cicindela littoralis var. lugens Dahl..", while two specimens were reported as "Cicindela littoralis var. aphrodisia Truqui". The figure that Ragusa provided of the "var. Lugens Dahl" (Ragusa, 1882: table 1 Fig. 1), as also confirmed by Cassola (1983), actually depicts a specimen of $C$. aphrodisia.

Two years later, aware of his mistake, Ragusa (1884) distinguished the "lugens Dejean", attributable to C. littoralis, from the "lugens" as interpreted by him (Ragusa, 1882), attributable to C. aphrodisia, and described the latter as a new variety ("var. lugens m.") (Fig. 11). Subsequently, Ragusa (1887) divided morphologically and biologically the two groups, C. littoralis and C. aphrodisia, and placed its variety lugens in the $C$. aphrodisia species group. Ragusa (1904) then described another Sicilian variety of $C$. aphrodisia ("Cicindela aphrodisia Baudi var. luctuosa Ragusa var. nov.”). 


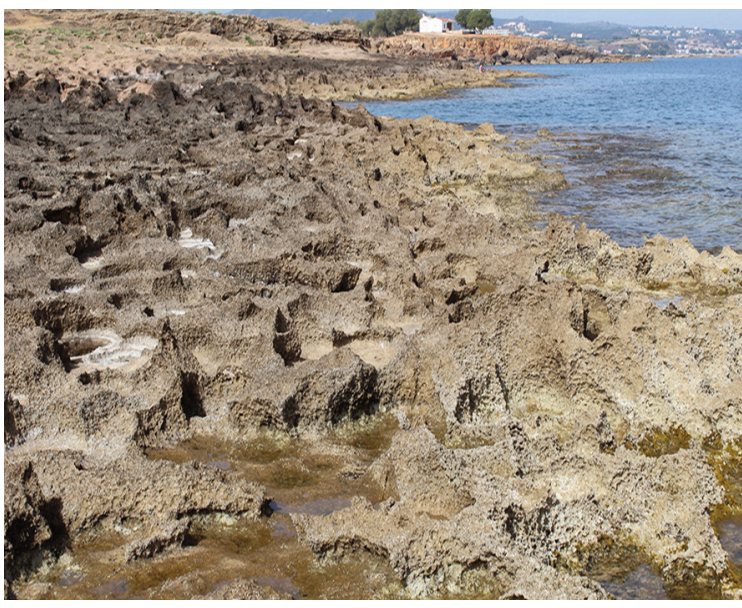

Figure 9. Crete (Greece), Chania, Daratsos: locus typicus of $C$. panormitana cretensis $n$. ssp.

Finally, Ragusa (1906), following a suggestion by Horn, the then leading specialist of Cicindelidae, described the C. aphrodisia of Sicily as a distinct taxon (panormitana, locus typicus Mondello near Palermo), and renamed its two aberrations of color (lugens and luctuosa) because those names were synonyms of names already used by Dejean for the genus Cicindela. Moreover, he clearly reiterated that his 1882 identification of lugens Dejean (Ragusa, 1882), probably for misinterpretation of some information received from other colleagues, did not concern a taxon of the C. aphrodisia group.

The examination of the Ragusa collection confirms all the above. There are both "lugens Ragusa" (in the group of $C$. aphrodisia, with the typical seven-shaped elytral spot) and the "lugens Dejean" in the group of the C. littoralis (a. lugens Dej.). In the same entomological drawer, the systematic order follows the state of the art in force at least until 1891 with C. aphrodisia, and therefore also these Sicilian populations, included in the C. aulica group (Dejean, 1831), subsequently separated as a species distinct from Horn \& Roeschke (1891; see also Ragusa, 1906).

In short, therefore, the taxon "lugens" as identified by Ragusa in 1882 is now C. panormitana. Conversely, according to Grandi (1906) and Horn (1926), the "var. lugens Dejean" corresponds to a variety of $C$. littoralis and this is confirmed by Porta (1923), who recorded the "var. lugens Dahl (Dejean)" only for Basilicata, among the Italian regions.

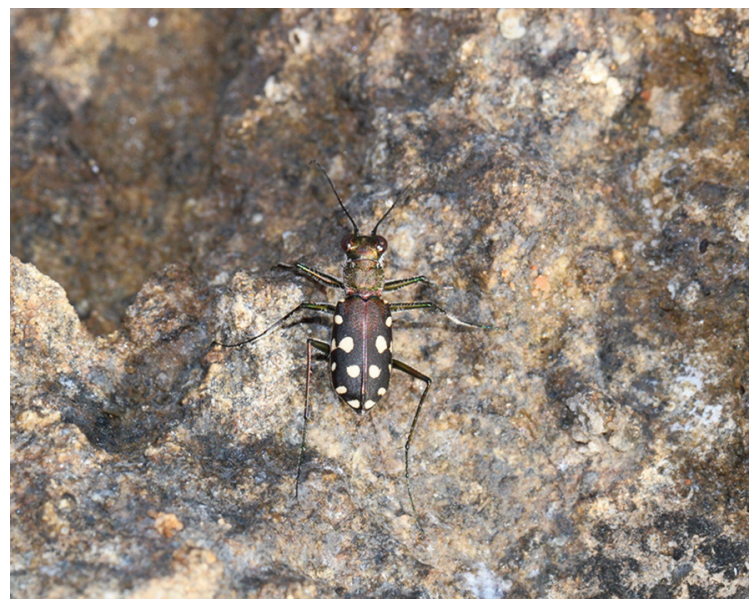

Figure 10. Calomera panormitana cretensis n. ssp. from Crete (Greece), Chania, Daratsos.

Cassola (1983) in a monographic work on $C$. panormitana confirms the above views. Wiesner (1992), without mentioning the sources, placed "panormitana" as a synonymous with "lugens Dejean, 1831", probably sensu Ragusa, 1882. Cassola (1999) reaffirms and extends its previous observations (Cassola, 1983), reconfirming that there is no reason to consider "panormitana" as a synonym of "lugens Dejean, 1831".

In fact, in the description of this variety (Dejean, 1831): there is no reference to the chromatic variety (seven-shaped elytral spot), characteristic of the Ragusa variety (1882); the locus typicus is Sicily and Morocco (where no species of the C. aphrodisia group occur); the only morphological datum indicates short elytra, while in the $C$. aphrodisia group all species and subspecies have elongated elytra.

The description of Dejean's variety is as follows (Dejean, 1831): "Cicindela littoralis Var. C. Lugens. Dahl M. Dahl m'a envoyé sous le nome del Lugens, des individus pris par lui en Sicilie, qui sont un peu moins allongès, et dont la couleur est presque noire en-dessus, mais qui ne me paraissent ce pendant qu'une simple variété de cette espèce. M. Goudot en a rapporté de semblables des environs de Tanger".

The type of this variety has never been mentioned in all of this cited bibliography and is not present in the Dejean collection, kept at the Museum of Natural History in Paris, where we have researched it ("... unfortunately I couldn't find the var. lugens" A. Taghavian-Azari, MNHN, in litteris). 


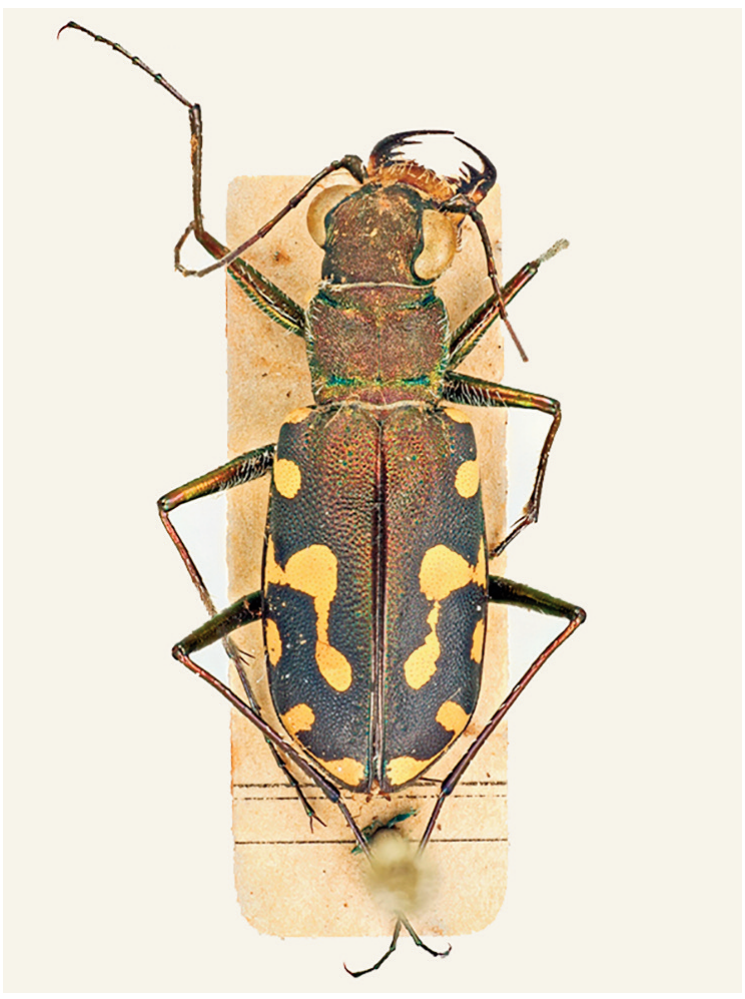

Figure 11. Calomera panormitana panormitana with seven-shaped elitral stains from E. Ragusa collection.

Even Ragusa (1902) had searched for this type without any result and it is not even in part of the Dejean collection kept in the Spinola collection (Giachino, 1982; R. Poggi in litteris).

For all these reasons, we establish here a neotypus attributable to $C$. littoralis nemoralis, because there is an exceptional need (art. 75 ICZN) for a nomenclatural stability with the following particulars: this neotype is designated with the express purpose of clarifying the taxonomic status of " $C$. lugens Dejean, 1831" and the type locality (75.3.1), to differentiate it from it from C. aphrodisia panormitana (75.3.2), to establish new data and a description sufficient to ensure recognition of the specimen designated (75.3.3.), considering that the type is lost or destroyed and that we have researched without finding it (75.3.4).

This neotype is consistent with what is known of the former name-bearing type from the original description ( art. 75.3.5) and from the original type locality (75.3.6), following the interpretations of almost all the authors mentioned. It is deposited in the collection of the Museum of Natural
History in Paris (75.3.7) (see Other examined material).

Calomera aphrodisia was described without its typical locality in a work that included material from Cyprus and Asia Minor (see Baudi di Selve, 1864, which however specified the location of the described species from Cyprus), but in these two locations there are two different populations. The typical locality, based on the original description, was established by Mandl (1981) only for Asia Minor, as accepted by all subsequent Authors. Mandl (1981) did not designate a lectotype, but reported having seen typical material present in the Kraatz collection. In the Baudi di Selve collection kept in the Museo Civico di Storia Naturale of Torino, in the typical series, there is a specimen (that seems to be attributable to C. aphrodisia from Asia Minor) without a label but with a small red label placed next to it.

In the original series of the entomological collection of E. Ragusa, preserved in the Institute of Environmental Biology of the University of Catania, we have selected a lectotype of C. panormitana, coherent with the indications of this author, while all other specimens have been labelled as paralectotypes (see Other examined material).

\section{CONCLUSIONS}

It is evident, even with this contribution, that $C$. aphrodisia is a morphologically well identifiable species, little variable, distributed along the continental coasts of Asia Minor from southern Turkey to Israel, clearly distinct from C. panormitana s.l.

On the contrary, in C. panormitana there are several widespread taxa, almost always insular, ranging from southern Turkey to Sicily, showing a greater morphological variability, probably due to allopatric speciations in progress.

They are, however, all relic populations, in constant rarefaction, with narrow ecological requirements, living only in rocky coasts, of great biogeographical importance.

Aliquò \& Romano (1976) and Cassola (1983) hypothesized that the greatest expansion of these populations occurred in the upper Miocene, when the salinity crisis of the Mediterranean Sea created new and greater territorial connections, facilitating their movements. Probably, these populations have 
reached Sicily, at the western limit of their distribution, through the new territories emerged during the salinity crisis, directly and without the aid of the more northern "Balkan-Apennine" bridges. This is demonstrated also by the presence in southern Italy and Sicily of animal and plant species with an Eastern Mediterranean origin showing little or no intermediate locality.

\section{ACKNOWLEDGMENTS}

We are grateful to Alberto Ballerio (Brescia, Italy), Fulvio Giachino (Museo Regionale di Scienze Naturali di Torino, Italy), Roberto Poggi (Museo Civico di Storia Naturale, Genoa, Italy), Giorgio Sabella and Fabio Viglianisi (Dipartimento di Biologia Animale University of Catania, Italy), and Azadeh Taghavian-Azari (Museum National d'Histoire Naturelle, Paris, France).

\section{REFERENCES}

Aliquò V. \& Romano F.P., 1976. Quinto contributo alla conoscenza della fauna coleotterologica della regione sicula (Cicindelidae, Carabidae). Bollettino della Associazione romana di entomologia, 30 (1975): 23-26.

Assmann T., Boutaud E., Buse J., Gebert J., Drees C., Friedman A.-L.-L., Khoury F., Marcus T., Orbach E., Renan I., Schmidt C. \& Zumstein P., 2018. The tiger beetles (Coleoptera, Cicindelidae) of the southern Levant and adjacent territories: from cybertaxonomy to conservation biology. ZooKeys, 734: 43-103. https://doi.org/10.3897/zookeys.734.21989

Austin K., Small E., Lemaire J.-M., Jeanne C., Makris C. \& Georghiou G., 2008. Révision du Catalogue des Carabidae (Coleoptera) de Chypre. A revised catalogue of the Carabidae (Coleoptera) of Cyprus. Annales du Museum d'Histoire Naturelle de Nice, 23: 1-199.

Aydın G., 2006. Evaluation of insects as bio-indicators for sustainable land use in Çukurova Delta. Çukurova University, Institute of Natural and Applied Sciences. PhD Thesis, 269 pp.

Aydin G., 2011. Conservation status of the Tiger Beetle Calomera aphrodisia (Baudi di Selve, 1864) in Turkey (Coleoptera: Cicindelidae), Zoology in the Middle East, 52: 121-123. DOI: 10.1080/09397140. 2011.10638489

Aydın G., Şekeroğlu E. \& Arndt E., 2005. Tiger beetles as bioindicators of habitat degradation in the Çukurova Delta, southern Turkey. Zoology in the
Middle East, 36: 51-58. DOI: 10.1080/ 09397140. 2005.10638127

Baudi di Selve F., 1864. Coleopterorum messis in insula Cypro et Asia minore ab Eugenio Truqui congregatae recensitio: de Europaeis notis quibusdam additis. Berliner entomologische Zeitschrift, 8: 195-233.

Cassola F., 1983. Studi sui Cicindelidi. XXXII. Note e osservazioni su un interessante endemita siciliano: Lophyridia aphrodisia panormitana (Ragusa) (Coleóptera Cicindelidae). Il Naturalista siciliano, 7: 41-56.

Cassola F., 1999. Studies on tiger beetles CVII. The cicindelid fauna of Anatolia: faunistics and biogeography (Coleoptera, Cicindelidae). Biogeographia, 20 (Biogeografia dell'Anatolia): 229-276.

Cassola F. \& Pearson D.L., 2000. Global pattern of the tiger beetle species richness (Coleoptera: Cicindelidae): Their use in conservation planning. Biological Conservation, 95: 197-208.

Choate P.M., 2010. Tiger Beetles of Florida, Cicindela spp., Megacephala spp. (Insecta: Coleoptera: Cicindelidae). Series of the Entomology and Nematology Department, Institute of Food and Agricultural Sciences, University of Florida. Document EENY-005 (IN131), 5 pp. See http://edis.ifas.ufl.edu.

Dejean P.F.M.A., 1831. Species général des Coléopterès. Tome Cinquième. Supplément aux cinq premiers volumes. Paris, chez Méquignon-Marvis: 195-276.

Franzen M., 2001. Distribution of the tiger beetle Lophyridia aphrodisia (Baudi, 1864) on the Turkish Mediterranean coast (Coleoptera, Cicindelidae). Zoology in the Middle East 23, 2001: 79-83.

Giachino P.M., 1982. La collezione coleotterologica di Massimiliano Spinola. Cataloghi del Museo Regionale di Scienze Naturali di Torino, 616 pp.

Grandi G., 1906. Sulle Cicindele lunulata Fabr. ed aulica Dej., e sulla loro varietà e distribuzione in Italia. Rivista coleotterologica italiana, 4: 85-107.

Horn W., 1891. Ueber die Artberechtigung der Cicindela aulica Dej. Un C. Aphrodisia Baudi. Deutsche entomologische Zeitschrift, 2: 332.

Horn W., 1926. Carabidae: Cicindelinae. In: Junk W. (Ed.), Coleopterorum Catalogus, Berlin, Pars 86: 345.

Horn W., 1931. Zur Kenntnis der Cicindelen-Fauna von Cypern, Syrien, Sizilien, Aegypten und SüdGriechenland (insbesondere der geografischen Verbreitung der Arten Cicindela aphrodisia, $C$. campestris suffriani, C. contorta und dorsata sowie C. aulica). Bulletin de la Société Royale Entomologique d'Egypte, 50: 157-163.

Horn W. \& Roeschke H., 1891. Monographie der Paläarktischen Cicindelen: Analytisch bearbeitet mit besonderer Berücksichtigung der Variationsfähigkeit und geographischen Verbreitung. Selbstverlag der Verfasser, Berlin. 
IUCN, 2017. The IUCN Red List of Threatened Species. Version 2017-3. http://www.iucnredlist.org (Last access: 05.VIII.2018).

Lisa T., 2002. Le Cicindele d'Italia (Coleoptera, Adephaga, Cicindelidae). Revue de l'Association Roussillonnaise d'Entomologie Supplément au Tome 11: $1-55$.

Korell A., 1988. Die Cicindeliden (Coleoptera) Anatoliens. Vorarbeiten für eine Faunistik nebst taxonomischen und systematischen Anmerkungen. Entomológica Basiliensia 12: 93-111.

Korell A., 1994. Die Cicindeliden Anatoliens (Coleoptera: Cicindelidae). Nachträge und Bemerkungen zur gleichnamigen Veröffentlichung in der "Entomológica Basiliensia", 12. Entomologische Zeitschrift, 104: 42-50.

Mandl K., 1981. Neun Formen aus der Familie Cicindelidae aus fünf Kontinenten (Col.). Koleopterologische Rundschau, 55: 3-18.

Pearson D.L. \& Cassola F., 1992. World-wide species richness pattern of tiger-beetles (Coleoptera: Cicindelidae): indicator taxon for biodiversity and conservation studies. Conservation Biology, 6: 376-391.

Pearson D.L. \& Vogler A.P., 2001. Tiger Beetles: the evolution, ecology and diversity of the cicindelids. Ithaca \& London, $333 \mathrm{pp}$

Rodriguez J.P., Pearson D.L. \& Barrera R.R., 1998. A test for the adequacy of bioindicator taxa: are tiger beetles (Coleoptera: Cicindelidae) appropriate indicators for monitoring the degradation of tropical forests in Venezuela? Biological Conservation, 83: 69-76.

Piochard de la Brulerie Ch., 1885. Catalogue raisonné des Coléopterès de la Syrie et l'île de Chypre, 1re partie. Famille des Cicindélides et des Carabides. Annales de la Société entomologique de France, 5: 100160.

Porta A., 1923. Fauna Coleopterorum Italica. Vol. I. Adephaga. Stabilimento Tipografico Piacentino, Piacenza, $285 \mathrm{pp}$.

Ragusa E., 1882. Coleotteri nuovi o poco conosciuti di Sicilia. Il Naturalista siciliano, 1: 5-9.

Ragusa E., 1883. Catalogo ragionato dei Coleotteri di Sicilia. Il Naturalista siciliano, 2: 169-173.

Ragusa E., 1884. Coleotteri nuovi o poco conosciuti di Sicilia. Il Naturalista siciliano, 3: 316-318.

Ragusa E., 1887. Coleotteri nuovi o poco conosciuti di Sicilia. Il Naturalista siciliano, 6: 214-216.

Ragusa E., 1904. Coleotteri nuovi o poco conosciuti di Sicilia. Il Naturalista siciliano, 17: 84.

Ragusa E., 1906. Coleotteri nuovi o poco conosciuti di Sicilia. Il Naturalista siciliano, 18: 247-250.

Sparacio I., 1994. Coleotteri di Sicilia. Vol. I. L'Epos, Palermo, 264 pp.

Tschitscherine T., 1903. Mémoire sur les Cicindélides des voyages de N. Zarudny dans la Perse orientale. Horae Societatis Entomologicae Rossicae, 36: 1-21.

Wiesner J., 1990. Beitrag zur Kenntnis der Cicindelidae (Coleoptera) von Rhodos. Entomologische Zeitschrift, 100 (18): 343-347.

Wiesner J., 1992. Verzeichnis der Sandlaufkäfer der Welt. Checklist of the Tiger Beetles of the World. Keltern. Wiesner J., 1994. Dritter Beitrag zur Kenntnis der Cicindelidae (Coleoptera) von Rhodos. Entomologische Zeitschrift, 104: 385-388. 